CRÍTICA, Revista Hispanoamericana de Filosofía

Vol. XXX, No. 90 (diciembre 1998): 89-96

\title{
REPLIES TO MY CRITICS
}

Some of the papers presented to the XVI International Symposium of Philosophy devoted to Donald Davidson were published in Critica no. 88. Both, the summaries of those papers and Donald Davidson's replies appear in what follows.

Crítica en su no. 88 publicó algunos de los artículos presentados en el XVI Simposio Internacional de Filosofía dedicado a Donald Davidson. A continuación aparecen los resúmenes de dichos artículos así como la respuesta de Donald Davidson.

THE THEORY OF MEANING AND THE PRACTICE OF COMMUNICATION

\author{
BARRY STROUD \\ University of California
}

\section{SUMMARY}

This paper expounds, endorses, and explores some of the consequences of Donald Davidson's observation that "there is no such thing as a language, not if a language is anything like what many philosophers and linguists have supposed". 
What many have supposed is that knowledge of a language is knowledge of the rules or conventions which govern the meanings of the expressiones of that language, and that speakers and hearers apply that general knowledge in saying things with meaning and understanding the utterances of others. Davidson argues that if that were so, no one would ever say something with meaning or understand the utterances of others, since even with a full theory of meaning for a language which would grind out the meaning of any arbitrary expression, there is "no portable interpreting machine set to grind out the meaning of an arbitrary utterance". Communicating involves saying something, and so doing something, and knowledge of the meanings of words alone cannot tell you what to do, or what someone else is doing. A parallel is drawn with Wittgenstein's denial of the idea "that if anyone utters a sentence and means or understands it he is operating a calculus according to definite rules". Difficulties faced by more "full-bodied" theories of meaning (such as Michael Dummett's) which rely on or demand some such "mental mechanism" to "deliver", and so to explain, a person's understanding of particular utterances are identified and discussed. The problem, so far unsolved, is to explain how meaning or understanding anything would be possible at all if that condition had to be met. Kripke's sceptical paradox is shown for the same reason to reduce to the claim that "there is no such thing as a person's meaning something, not if meaning is anything like what many philosophers have supposed".

\section{RESUMEN}

Este artículo expone, aprueba y explora algunas de las consecuencias de la observación de Donald Davidson en el sentido de que "no hay tal cosa como un lenguaje, no si 
un lenguaje es cualquier cosa parecida a lo que muchos filósofos y lingüistas han supuesto". Lo que muchos han supuesto es que el conocimiento de un lenguaje es el conocimiento de las reglas o convenciones que gobiernan los significados de las expresiones de ese lenguaje, y que los hablantes y oyentes aplican ese conocimiento general al decir cosas con significado y entender las emisiones de otros. Davidson argumenta que, si las cosas fueran así, nadie diría nunca algo con significado o entendería las emisiones de otros, pues incluso si se cuenta con una teoría completa del significado para un lenguaje que produjera mecánicamente el significado de cualquier expresión arbitraria, no hay "ninguna máquina portátil para interpretar que produzca mecánicamente el significado de una emisión arbitraria". La comunicación involucra decir algo, y por tanto hacer algo, y el solo conocimiento de los significados de las palabras no puede decirnos qué hacer, o qué es lo que alguien más está haciendo. Se establece un paralelismo de lo anterior con el rechazo por parte de Wittgenstein de la idea "de que si alguien emite un enunciado y quiere decir lo que el enunciado significa o lo entiende está haciendo funcionar un cálculo de acuerdo con reglas definidas". Se identifican y discuten las dificultades que enfrentan las teorías del significado con "más cuerpo" (como la de Michael Dummett) que se apoyan en, o exigen que, un "mecanismo mental" semejante "suministre", y de esa manera explique, la comprensión que tiene una persona de emisiones particulares. El problema, hasta ahora no resuelto, consiste en explicar cómo significar o entender cualquier cosa sería posible en absoluto si esa condición tuviera que ser satisfecha. Por la misma razón, se muestra que la paradoja escéptica de Kripke se reduce a la afirmación de que "no hay tal cosa como el que una persona quiera decir algo con sus palabras, no si querer decir algo es como lo que muchos filósofos han supuesto". 
THE CONSTITUTIVE IDEAL OF RATIONALITY: DAVIDSON AND SELLARS

\author{
JoHn McDoweLL \\ University of Pittsburgh
}

\title{
SUMMARY
}

Davidson invokes the constitutive ideal of rationality in arguing that concepts of propositional attitudes are irreducible to concepts that might pull their weight in nomothetic science. Richard Rorty has recently deplored the suggestion that there is anything special about this irreducibility. In Rorty's view such a suggestion is out of line with Davidson's better wisdom; it merely encourages a conception of philosophy that he and Davidson both want to discourage. In the first part of my paper, I defend Davidson against this accusation. I align the feature of Davidson's thinking that Rorty deplores with a central feature of the thinking of another of Rorty's heroes, Wilfrid Sellars. And I urge that, so far from encouraging philosophy in a Cartesian vein, as Rorty fears, the irreducibility thesis that is common to Davidson and Sellars is a central element in a satisfying exorcism of the temptation to suppose that philosophy must take that sort of shape.

In the second part of the paper, I trace a misunderstanding by Rorty of Davidson's semantical reflections to a Sellarsian blind spot about Tarski. I suggest that if we understand how Davidson's semantical thinking is superior to that of Sellars and Rorty, we can see a way to reclaim an innocent idea of the subjective, as essentially related to the objective, without in any way defending what Davidson dismisses as the Myth of the Subjective. This would be a further contribution to the dismantling of Cartesian assumptions. 


\section{RESUMEN}

Davidson invoca el ideal constitutivo de la racionalidad al argumentar que los conceptos de las actitudes proposicionales no son reducibles a conceptos que podrían tomar parte en la ciencia nomotética. Recientemente Richard Rorty ha deplorado que se sugiera que hay algo especial con respecto a esta irreducibilidad. Según Rorty, tal sugerencia no concuerda con las mejores ideas de Davidson; simplemente alienta una concepción de la filosofía que tanto él como Davidson quieren desalentar. En la primera parte de mi artículo defiendo a Davidson de esa acusación. Vinculo la característica del pensamiento de Davidson que Rorty deplora con una característica central del pensamiento de otro de los héroes de Rorty, Wilfrid Sellars, e insisto en que, lejos de alentar a la filosofía a adoptar una vena cartesiana, como teme Rorty, la tesis de la irreducibilidad que es común a Davidson y Sellars es un elemento central de un exorcismo satisfactorio de la tentación de suponer que la filosofía debe tomar ese tipo de forma.

En la segunda parte del artículo muestro que cierto malentendido de Rorty acerca de las reflexiones semánticas de Davidson se origina en un punto ciego de Sellars con respecto a Tarski. Sugiero que si entendemos cómo el pensamiento semántico de Davidson es superior al de Sellars y Rorty, podemos apreciar una forma de reivindicar una idea inocente de lo subjetivo, entendido como algo esencialmente relacionado con lo objetivo, sin defender de ninguna manera lo que Davidson descarta como el Mito de lo Subjetivo. Esto sería una contribución más al desmantelamiento de supuestos cartesianos. 


\title{
DAVIDSON BETWEEN WITTGENSTEIN AND TARSKI
}

\author{
RICHARD RORTY \\ University of Virginia
}

\section{SUMMARY}

Davidson's adherence to the Quinean doctrine of the "special" indeterminacy of translation is puzzling to those who take seriously Davidson's claim to eliminate the difference between understanding language and finding our way about the world. But perhaps that adherence can be viewed, following Ramberg, as a somewhat misleading way of saying that norms are inescapable because the process of what Davidson calls "triangulation" is inevitable.

Fans of "A Nice Derangement of Epitaphs" are also puzzled by Davidson's claim that understanding utterances consists in applying a truth-theory which are related to their doubts about the purported indeterminacy of translation. The lesson of the concluding paragraphs of "A Nice Derangement" would seem rather to be that we should view the ability to understand utterances as like the ability to ride a bicycle. Both can be viewed as know-how rather than as the application of a theory of any sort. Taking this tack would move Davidson away from Tarski, and any attempt at a systematic theory of meaning, and towards Wittgensteinian therapeutic.

\section{RESUMEN}

La adhesión de Davidson a la teoría quineana de la indeterminación "especial" de la traducción resulta desconcertante para quienes toman seriamente la propuesta de Davidson de eliminar la diferencia entre comprender el lenguaje y 
saber cómo conducirnos por el mundo. Sin embargo, quizá sea posible, siguiendo a Ramberg, considerar esa adhesión como una forma algo engañosa de decir que las normas son inevitables porque el proceso que Davidson llama "triangulación" es ineludible.

Los aficionados de "A Nice Derangement of Epitaphs" también experimentan un desconcierto ante la afirmación de Davidson de que la comprensión de emisiones consiste en la aplicación de una teoría de la verdad, lo que se relaciona con sus dudas acerca de la supuesta indeterminación de la traducción. La enseñanza de los últimos párrafos de "A Nice Derangement" parecería ser más bien que deberíamos equiparar la capacidad de entender emisiones con la capacidad de andar en bicicleta. Ambas capacidades pueden considerarse como un know-how antes que como la aplicación de una teoría de cualquier tipo. La adopción de este enfoque alejaría a Davidson de Tarski y de cualquier intento de construir una teoría sistemática del significado, y lo acercaría al quietismo terapéutico de Wittgenstein.

\section{IS THERE SUCH THING AS A LANGUAGE?}

\section{Carlos Pereda}

Instituto de Investigaciones Filosóficas

UNAM

\section{SUMMARY}

Three models intended to reconstruct what we mean by language are examined in order to discuss and understand better Davidson's following assertion: "there is no such thing as a language". Seemingly, Davidson wishes to attack the first model, or model of "communicative determinism" 
- diverse forms of Platonism, formal semantics - by advancing what I call the model of "communicative indeterminism". I defend as an alternative to these two models a third option: "communicative underdeterminism": language as an "anomalous institution", or as a "natural institution".

\section{RESUMEN}

Se discuten tres modelos de pensar en el lenguaje con el propósito de entender mejor, y discutir, la siguiente afirmación de Davidson: "no hay tal cosa como un lenguaje". Davidson parecería querer atacar, ante todo, el primer modelo o modelo del "determinismo comunicativo" (diversas formas de platonismo, la semántica formal) proponiendo lo que llamaré un modelo del "indeterminismo comunicativo". Como alternativa a ambos modelos defiendo una tercera opción: el "subdeterminismo comunicativo", el lenguaje como una "institución anómala", como una "institución natural". 
CRÍTICA, Revista Hispanoamericana de Filosofia

Vol. XXX, No. 90 (diciembre 1998): 97-112

\section{REPLIES}

Donald DaVIDSON

The University of California at Berkeley

These essays give me much pleasure. They are written by friends with my welfare in mind, showing the measured attention and understanding one always secretly hopes for, and full of avuncular advice gently administered. They are friends of each other, of mine, and of philosophy, and when it comes to a choice, they prove they would not be such good friends loved they not philosophy more. This practically ensures that they do not always agree with each other, or with me, and where one agrees with me, another differs. It will not harm this happy state of affairs if I try to bring about agreement, for the more agreement there is (or so I have always argued), the more intelligible and rewarding further discussion will be.

Richard Rorty sees some of my views as serving his Wittgensteinian agenda, which is flattering if deserved. He is less pleased by my persistent interest in Tarskian semantics. Like many others, he views these tendencies as opposed, and urges me to forgo the second. But I can't, because what Rorty holds to be antithetical modes of philosophizing I see as interdependent aspects of the same enterprise. Insofar as I have arrived at, or remembered, Wittgensteinian thoughts, it is largely through having tak-

(c) Donald Davidson, 1998. 
en a third person approach to the problems of intentionality, and this is an approach which has always seemed to me to require (along with much more) the framework provided by the structures of formal semantics and decision theory. Rorty suggests that you can grasp my arguments for saying that interpreting a speaker involves knowing one's way around in the world even if you have no interest in a systematic theory of language. But I did not say that knowing one's way around in the world didn't include skills that can only be described by appeal to a formal theory. I'll revisit these matters presently. But now I turn to Rorty's first suggestion, that I give up subscribing to Quine's thesis of the indeterminacy of translation, or, as I translate it, the indeterminacy of interpretation.

What he fears is that this thesis implies that there is something mysterious, second rate, or even not quite real, about the mental, that there are no "facts of the matter" about meaning or the propositional attitudes. Let me put his mind at rest on this score. In my view, the mental is no more mysterious than molecular biology or cosmology. Our mental concepts are as essential to our understanding of the world as any others; we could not do without them. The propositional attitudes, such as intentions, desires, beliefs, hopes and fears, are every bit as real as atoms and baseball bats, and the facts about them as real as the facts about anything else. How could there be a question about the ontology of mental entities for me if, as I hold, they are identical with entities we also describe and explain, in different terms, in the natural sciences?

Rorty's fears are partly based on an early mistake of mine. In "Mental Events" I did maintain that the irreducibility of mental concepts was due, among other things, to the indeterminacy of interpretation. This was wrong, as I have since admitted. The error is obvious: indeterminacy as I understand it is endemic in all disciplines. Indeterminacy 
is nothing more than the flip side of invariance. Indeterminacy occurs whenever a vocabulary is rich enough to describe a phenomenon in more than one way. It doesn't matter whether you say Sam is to the left of Susan, or that Susan is to the right of Sam. If you have the axioms that define some system of measurement, whether it is of weight, temperature or subjective probability, you can represent the structure so defined in numbers in endless ways. What matters is what is invariant. With weight, an arbitrarily chosen positive number is assigned to some particular object; relative to that assignment, the numbers that measure the weights of all other objects are fixed. So you can get an equally good way of keeping track of weights by multiplying the original figures by any positive constant; it's the ratios that are invariant. Only invariances are "facts of the matter".

This is how I understand the indeterminacy of translation and interpretation. Given the richness of all natural languages, it would be surprising if it were not always possible to describe the facts of any discipline in many ways. Such indeterminacy does not threaten the reality of what is described. Of course, confusion results if we do not take into account the relativity of some way of describing things to the appropriate scale or mode of description: it matters whether your numbers are Fahrenheit or Centigrade, your weights pounds or kilos, your distances miles or kilometers. The analogy with the case of sentences or the contents of propositional attitudes is this: Each of us can think of his own sentences (or their contents) as like the numbers; they have multiple relations to one another and to the world. Keeping these relations the same, we can match up our sentences with those of a speaker, and with the attitudes of that speaker, in different ways without changing our minds about what the speaker thinks and means. Just as endless sets of numbers allow us to keep track of the same 
complex structures in the world, so our sentences can be used in endless different ways to keep track of the attitudes of others, and of the meanings of their sentences. Quine made this point in order to emphasize that there is no more to the identification of meanings than is involved in capturing these complex empirical relations. This can sound like a negative thesis, and it is; it is an attack on the idea that meanings can be captured in exactly one way, by pinning Platonic meanings on expressions. But this negative point does not entail that there are no facts of the matter; the facts are the empirical relations between a speaker, her sentences, and her environment. This pattern is invariant.

If we actually employed more of the possible ways of reporting what someone means and thinks, we would want to be explicit about the system we were using. In practice, we pretty much stick to one way; it's as if everyone spoke Centigrade or Miles or Kilograms. But for theoretical purposes, it is good to know what our assignments are relative to; they are relative to a language. Not our own language, of course, but the language of the speaker or agent. When in our ordinary dealings with others we make small adjustments in our reporting of what someone meant or thought, we silently change the language we take that person to be speaking. Quine calls this changing the translation manual, but this makes it seem that there is something in addition to the usual relativity of a theory of meaning to a language, while in fact only one relativization is required, and it is familiar.

Rorty says he discerns no distinction between the underdetermination of a theory and indeterminacy. I do. Theories are interesting and valuable mainly because they entail what hasn't been observed, particularly, though not only, in the future. It is an empirical question whether such a theory holds for the unobserved cases - a question to which we shall never know the answer. As Hume and Nelson Good- 
man have told us, there are endless things that may happen next, many of which would confirm theories at odds with our present theories. This is underdetermination. Indeterminacy is not like this; no amount of evidence, finite or infinite, would decide whether to measure areas in acres or hectares.

John McDowell is clear that nothing I say makes the mental mysterious or any less real than the subject matter of the natural sciences. He also agrees with me that there is a reason to emphasize the irreducibility of the mental, but only because the irreducibility springs from something more interesting than the indeterminacy of translation and interpretation. He rightly stresses the constitutive role of normativity in all mental or psychological concepts. This was what I had made central in "Mental Concepts" (1970), and again in "Three Varieties of Knowledge" (1991), where I took back the claim that the irreducibility of mental concepts followed from the indeterminacy of interpretation. The mental vocabulary isn't "privileged" because it is irreducible (as Rorty thinks I think); it is irreducible because it is normative.

Normativity is constitutive of the mental because the mental is built on a framework of attitudes which have a propositional content, and propositions have logical relations to one another. Reasoning, no matter how simple and unstudied, is a matter of putting thoughts together in ways that are assessable as reasonable both by the agent and by others. Every action is describable in terms of intentions, and intentions are based on reasons that are, again, judged as rational or not by the agent and others. All genuine speech is intentional, and can be understood only by interpreters equipped to grasp key intentions of speakers. The norms I am mainly concerned with are not the norms of responsibility, trustworthiness, morality. The basic "virtue" that sets mental concepts off from those of 
the natural sciences is the special sort of charity required for understanding the thoughts, speech, and other actions of agents, and such charity is not a virtue, but simply a condition of understanding others at all (and so, of course, it is a necessary preliminary to treating others as moral agents). ${ }^{1}$

Charity is a matter of finding enough rationality in those we would understand to make sense of what they say and do, for unless we succeed in this, we cannot identify the contents of their words and thoughts. Seeing rationality in others is a matter of recognizing our own norms of rationality in their speech and behavior. These norms include the norms of logical consistency, of action in reasonable accord with essential or basic interests, and the acceptance of views that are sensible in the light of evidence. These various norms can suggest conflicting ways of interpreting an agent (for example, there are different things an agent may mean by what she says), and there may be no clear grounds for preferring one of these ways to others. Balancing the claims of competing norms in interpretation thus introduces a form of indeterminacy not found in the indeterminacy that abounds in physical measurement. This is the connection between indeterminacy and the irreducibility of the mental I had in mind in "Mental Events"; it is badly expressed in the passage from that essay which McDowell quotes at the start of his paper. It is a special twist the norms of rationality impart to interpretation.

Such indeterminacy does not make the mental mysterious or unreal, nor does it suggest that there is no fact of the matter about what people think and mean; it is a harmless consequence of the fact that there is more than

1 I am happy to have McDowell remind me of Wilfrid Sellars's "Empiricism and the Philosophy of Mind" in this connection. I read it many years ago and was permanently influenced, though what I remembered learning there was the attack on the Myth of the Given. 
one way of describing what is invariant. But whether or not one accepts the thesis of indeterminacy, here we come to something that puts an end to a certain regress. For when we ask where the norms come from that each of us applies in understanding others, the answer is that they cannot be derived from a source outside ourselves, for any attempt to check with others drives us back to the process of interpretation in which we necessarily employ our own norms. This is the step Rorty says he has come to understand, having been persuaded by Bjørn Ramberg's perceptive paper. As Rorty puts it, "the inescapability of norms is the inescapability, for both describers and agents, of triangulating".

McDowell and I seem to have in mind the same distinction between mental concepts and those of the natural sciences, and we agree that it is the rationality of propositional thought that sets the mental apart. ${ }^{2}$ There also seems to be a shade of difference in how we want to describe the distinction. He writes:

The separation of logical spaces or constitutive ideals that underwrites the irreducibility thesis reflects a distinction between two ways of finding things intelligible. Both involve placing things in a pattern. But in one case the pattern is constituted by regularities according to which phenomena of the relevant kind unfold; in the other it is the pattern of a life led by an agent who can shape her action and thought in the light of an ideal of rationality.

2 I am surprised to find Rorty, who is so opposed to distinguishing the mental vocabulary from the vocabulary of natural science, buying the old positivist distinction between the "descriptive vocabulary of intentionality" and the "prescriptive vocabulary of normativity". Maybe there is some respectable way to set apart the concepts sometimes conveyed by words like "obligation", "duty", "right" and "good" from mental concepts, but I would say both sorts of concepts are based on norms, and both are descriptive. 
It is only the last sentence that gives me pause. I agree that the norms of rationality do define a "pattern of life led by an agent who can shape her action and thought in the light of an ideal of rationality". But this is only one feature of "the space of reasons". Whether or not an agent "shapes" her action and thought in the light of an ideal, and whether she acts or thinks well or badly, when we represent her thoughts and actions to ourselves as thoughts and actions, we have placed her in the space of reasons. Perhaps McDowell would agree. My more serious misgiving concerns the implication that mental concepts, unlike those of the natural sciences, are not concerned with "regularities" (elsewhere he calls them laws). The point of concepts is to classify things, and concepts survive only if they are found useful. "Useful" here means leading to valuable generalizations. I have myself urged that the generalizations mental concepts lend themselves to are less strict than those physics aims for, but they are ones we could not live without. Many mental traits are, or at least involve, dispositions, and dispositions are, of course, lawlike. If we know what someone wants, we know a lot about the circumstances under which she is apt to act; similarly for beliefs, conditional intentions, and a host of features of personalities like pride, generosity, ambition, courage, lasciviousness, and so on.

I cannot go along with McDowell when he says that what I call the myth of the subjective cuts against the idea that "mental acts are intrinsically characterized by being semantically related... to elements in the extra-mental order". I like McDowell's defense, as against Sellars and Rorty, of the "relational" conception of semantics, and the importance he attaches to it. But what I called the Myth is the view that there are mysterious entities "before the mind" which come between our thoughts about the world and the world itself, what I have called "epistemological intermediaries". I do not deny that we often perceive how the world 
is, or that perceiving is an "experience" (though the scare quotes register my distrust of accounts that assume the meaning of the word is clear enough to explain the nature of perception).

McDowell has an agenda that is not fully expressed in this paper. Rorty brings it out when he says I hold that "empirical content can be intelligibly in the picture even though we carefully stipulate that the world's impacts on our senses have nothing to do with justification". He is right that sense data, uninterpreted experience, sensations, do not justify our beliefs, and in this the three of us agree. Our difference is this: Rorty and I think the interface between our bodies and the world is causal and nothing more, while McDowell holds that the world directly presents us with propositional contents. McDowell sees no trouble in accounting for the contents of perception, since nature provides these. I have the problem, which I think a form of externalism at least partly solves, of explaining how external features of the world cause us, through the medium of the senses, to form largely correct beliefs. This is a debate I look forward to pursuing on future occasions.

Rorty thinks I make too much of the concept of truth. I have come to agree with Rorty that there is no point in calling truth a norm or a goal. No doubt it is often desirable to believe or say what is true, because we are then more apt to get what we want. But there is no guarantee that the true and the good will coincide; the goal, after all, is the desired outcome, not the truth. In searching for the truth we check our sources, ask the experts, repeat our experiments with more controls, and so forth. There isn't some further activity we can undertake which will prove that we have arrived at the truth. So it would be better to say that our goal (and a legitimate norm) is to be justified; but of course we can be justified and wrong. 
The importance of the concept of truth is rather its role in understanding, describing, and explaining the thought and talk of rational creatures. The best way of characterizing an important part of what someone knows who understands and speaks a language is to give a systematic account of the truth conditions of the sentences of that language. We do not grasp the concept of belief if we do not know that a belief may be true or false, nor do we know what it is that someone believes if we do not know under what conditions it would be true. We do not have a concept unless we know what it would be for it to apply to (be true of) some things and not to others. Rorty is willing, I think, to allow that the concept of truth has these uses, but he reminds us that it has many other uses, and that there are other concepts that play as central a role in our mental equipment. I am happy to grant both points, with the proviso that many of the uses of "true" that Rorty mentions would be hard to understand if we did not grasp what I take to be the basic use.

I am sure that a philosopher may be interested in many things while not giving a hoot about formal, or semi-formal, semantics as applied to natural languages. But why does Rorty mind if I, Barry Stroud, John McDowell, and Carlos Pereda happen to find formal semantics useful, interesting, and capable of throwing light on a number of concepts such as truth, the validity of logical inferences, the learnability of natural languages, and relations between a speaker and the world as mediated by language? He does not say, but I suspect that his distaste springs in part from the fear that by formulating this relation, normal semantics is in danger of encouraging the dread idea that language and thought represent or mirror the world. But there is no danger. Tarskian semantics introduces no entities to correspond to sentences, and it is only by introducing such entities that one can make serious sense of language mir- 
roring or corresponding to or representing features of the world. As McDowell says, the simple thesis that names and descriptions often refer to things, and that predicates often have an extension in the world of things, is obvious, and essential to the most elementary appreciation of the nature both of language and of the thoughts we express using language. Sellars was wrong to deny the thesis, and so is Rorty in holding it suspect.

Stroud and Rorty both like "A Nice Derangement of Epitaphs", but for different reasons. Rorty likes it because it seems to break down the distinction between the sort of meaning that formal semantics deals with and the rest of what we know about the world. Stroud likes it because, while recognizing the role of formal semantics in understanding language, it denies that knowledge of such a theory is either necessary or, more importantly, sufficient for understanding a speaker. Since what Stroud emphasizes in my essay is a Wittgensteinian point, Stroud's position suggests how Rorty might be persuaded to accept my perverse interest in Tarskian semantics.

Before taking up this theme, I want to correct two misleading features of "A Nice Derangement of Epitaphs". The first is this: I failed to distinguish sufficiently clearly between two points I wanted to make: that people don't need to speak the same language in order to understand each other, and that the same person needn't continue to speak as he has in the past in order to be intelligible. Some examples illustrate both of these theses, but the issues are separable. An example of the first kind would be a fluent speaker of Spanish and a fluent speaker of Portuguese, each speaking his own language, but being perfectly understood by the other. These two languages have much in common, but obviously a similar situation could involve speakers of very different languages. I gave several examples of the second kind in my essay; such examples show that the in- 
terpreting hearer frequently has no trouble comprehending words she has never heard before, even words that have never been spoken before. Cases of these two kinds are enough to show that there is more to understanding (and therefore speaking intelligibly) than is involved in speakers' and interpreters' being supplied with identical kits of rules.

The second way I have mislead readers is by sometimes writing as if I thought speakers and interpreters have, and form, theories of meaning on the basis of which they speak and interpret. Stroud asks why I would want to speak of a theory in the case of Mrs. Malaprop, and Rorty dumps on the idea that people ever operate with theories of meaning. He has a proposal:

Why not treat the work of grammarians and lexicographers (or their ideal counterparts, the devisers of Tarskian truthdefinitions...) as bearing the same relation to the speaker in the street as the physical scientists bear to the bicycle-rider on the road?

I took this advice long before it was given. Almost from the start I held that those who use language do not normally have a theory; all I asked of a satisfactory theory in this respect was that if someone had such a theory for a speaker, at a time, that theory would suffice for understanding an arbitrary utterance of that speaker, at that time (see, for example, the first paragraph of "Radical Interpretation", 1973). Somewhat more recently I have taken to emphasizing that it is the philosopher, trying to understand understanding, who needs the theory in order to say what it is that the interpreter knows if he understands a speaker. A flawless interpreter is prepared, I thought, to interpret anything a speaker says - a potential infinity of utterances. So the interpreter knows what is conveyed by every T-sentence entailed by a theory of truth for the speaker's language, 
and only a theory can specify this totality in finite terms. I have always been clear that this does not suggest that the flawless interpreter knows such a theory.

A number of readers sense a conflict between the importance I assign to formal semantical theories and the "there is no such thing as a language" attitude of "A Nice Derangement of Epitaphs". Among such readers are Pereda and Rorty. Pereda has the sensible idea of trying to reconcile the Wittgensteinian and Tarskian modes by emphasizing the importance of a general institutionalized linguistic background against which deviant verbal behavior is understood, while Rorty just wants me to abandon the theorizing. I see nothing wrong with Pereda's view, as long as it is taken as saying that members of a "speech community" share a host of overlapping, non-identical, habits of speech, and have corresponding expectations about what others in the community will mean by what they say (such a set of expectations is what is characterized by what I called a "prior theory"). It would be possible for each speaker to have a radically different language; then each hearer would have to extemporize a mode of interpretation. In practice this would be intolerable, perhaps humanly impossible: hence the survival value of conforming.

But does it make sense to speak of a theory in the case of Mrs. Malaprop? The idea I had in mind was simple. An interpreter in a particular conversational situation is prepared with a general set of expectations (which the "prior theory" describes). When expectation is thwarted, what is novel is (usually automatically) accommodated (read "arrangement" for "derangement", "epithets" for "epitaphs"). If the speaker goes on like this, these substitutions in all possible contexts yield a new language, which can be delineated by a "passing theory". Slots in the "prior theory" have been filled in new ways. The apparatus of a "prior 
theory" and "passing theory" was an unnecessarily cumbersome way of expressing this thought.

Knowing a language is, in some respects, like knowing how to ride a bicycle. In both cases, as Rorty points out, we talk of knowing how, and in neither case is it necessary or common to know a theory that explains what we do. But there are also striking differences. There are endless things a speaker or interpreter must know: the truth conditions a hearer will probably take her utterances to have, the truth conditions that most of the sentences she hears will have, relations of entailment, contradiction, and evidential support among sentences. And this is just a start, as I argued in "A Nice Derangement of Epitaphs". Bicycle riding requires no propositional knowledge at all. Speechless animals can be taught to ride bicycles.

Barry Stroud correctly catches my attitude towards many of these issues. He is right that I don't deny that people learn to speak one or more languages, which equips them "in advance" to understand much of what they hear. This is because, as he says, there are a lot of regularities in how people talk; "there is nothing else for a theory of meaning of a particular language to capture". And Stroud is certainly right when he says that I am against the idea that we understand speakers by appealing to or applying, rules, conventions or a theory. Unlike Stroud, however, I balk at using words like "rule" or "convention" to describe what speakers of what is called the same language share. My reason is that it seems to me we have said it all when we say that some speakers speak in much the same way, and that therefore speakers and hearers have natural expectations about how their words will be understood, and what other speakers will mean by what they say. My objection to assimilating regularities to rules or conventions is that the latter sound like norms, and I do not believe there are norms inherent in language itself. Of course there are plen- 
ty of norms that bear on what we say when. I don't deny that it is virtuous to try to preserve valuable distinctions, that we are wise to speak in a way that will be understood by others, or that efforts should be made to keep Basque from dying out. But these are norms entirely contingent on further values, not intrinsic values of language. It is wrong, normally, to act counter to a convention; there is nothing inherently wrong in twisting language any way we want.

There are many ways in which we may fail in our intentions in speaking, and these are sometimes confused with one another. We may think we are saying something true when we are not. In this case the error is not linguistic; our error is in saying and believing what is false. (Of course, in learning a new word, there is no point in this distinction: error, linguistic or otherwise, is not yet in the picture.) $\mathrm{Or}$ we may think a word or expression we are using usually (or in the best company, or in a good dictionary) means something it does not; this is an error in what we believe about the speech habits of others, or of lexicographers, but it would not be a communicative error unless we fail in our intention to be understood. I don't think of T-sentences as normative in themselves: they don't, for example, tell us what truth conditions we ought to assign to a sentence, nor do they tell us when we would be "correct" to assert it, unless "correct" here just means "true". T-sentences are descriptive: I think of them as describing a practice. Using a T-sentence to interpret a speaker whose practice at the moment it correctly describes will yield a correct interpretation, or at least so I have long held, and still do.

Why, then, does Stroud say, as if he agreed with me, "A theory of meaning alone does not suffice for interpreting speech, even in the normal case in which a single, widelyshared language is being used correctly"? He says it because he does agree with me, and has correctly understood the principle theme of "A Nice Derangement of Epitaphs". 
The point is, as Stroud says, that even if one has a "prior theory" which not only correctly describes a widely-shared linguistic practice, but also correctly applies to the case in hand, one still must apply that theory to the case in hand (or simply interpret the present utterance in accord with the theory), and no theory tells us to do that. Stroud reminds us that according to Wittgenstein there must be a way of interpreting or understanding something which is not a matter of following instructions or being guided in one's interpretation. The reason is simple. The kind of knowledge a theory of meaning describes is not irrelevant. But it never can instruct us when to apply it. The knowledge on which we rely, however intuitively, is just about everything we know. This is why I wrote that

there are no rules for arriving at passing theories, no rules in any strict sense, as opposed to rough maxims and methodological generalities. A passing theory really is like a theory at least in this, that it is derived by wit, luck, and wisdom from a private vocabulary and grammar, knowledge of the ways people get their point across, and rules of thumb for figuring out what deviations from the dictionary are most likely. There is no more chance of regularizing, or teaching, this process than there is of regularizing or teaching the process of creating new theories to cope with new data in any field... 